\title{
INFRARED AND RAMAN SPECTRA OF THE CUBIC FORM OF MAGNESIUM CESIUM ARSENATE HEXAHYDRATE
}

\author{
Viktor Stefov $^{1,2}$, Violeta Koleva ${ }^{3}$, Metodija Najdoski ${ }^{1,2}$, Adnan Cahil $^{4}$, Zuldjevat Abdija ${ }^{5}$ \\ ${ }^{1}$ Instiute of Chemistry, Faculty of Science and Mathematics, University of "Ss. Cyril and Methodius", \\ P.O. Box 162, 1001 Skopje, Republic of Macedonia \\ ${ }^{2}$ Research Center for Environment and Materials, Macedonian Academy of Sciences and Arts, \\ Skopje, Republic of Macedonia \\ ${ }^{3}$ Institute of General and Inorganic Chemistry, Bulgarian Academy of Sciences, 1113 Sofia, Bulgaria \\ ${ }^{4}$ Pedagogical Faculty, Ss. Cyril and Methodius University, Skopje, Republic of Macedonia \\ ${ }^{5}$ Faculty of Natural Sciences and Mathematics, "University of Tetovo”, Tetovo, Republic of Macedonia \\ viktorst@pmf.ukim.mk
}

\begin{abstract}
Fourier transform infrared (FT-IR) spectra recorded at room temperature (RT) and at the boiling temperature of liquid nitrogen (LNT), as well as Raman spectra recorded at room temperature for the cubic polymorph of magnesium cesium arsenate hexahydrate $\left(\mathrm{MgCsAsO}_{4} \cdot 6 \mathrm{H}_{2} \mathrm{O}\right)$ and its partially deuterated analogues, were interpreted with respect to the normal modes of the water molecules and the arsenate ions and water librations. The spectral characteristics of $\mathrm{MgCsAsO}_{4} \cdot 6 \mathrm{H}_{2} \mathrm{O}$ were compared to the cubic form of the phosphate analogue. A spectral similarity between the two isostructural salts was established, except for the obvious differences due to the nature of the anions $\left(\mathrm{AsO}_{4}{ }^{3-} v s \mathrm{PO}_{4}{ }^{3-}\right)$. The spectroscopic data for the uncoupled OD stretching mode of the matrix-isolated HDO molecules revealed that the hydrogen bonds formed in the arsenate salt were stronger than those in the phosphate. In the Raman spectrum of the protiated compound, only one very intensive band at $811 \mathrm{~cm}^{-1}$ was observed in the region of the stretching vibrations of the $\mathrm{AsO}_{4}{ }^{3-}$ ion, which was insensitive to deuteration. In accordance with the expectation, one band appeared in the same spectral range in the infrared spectra of the protiated and highly deuterated sample at $792 \mathrm{~cm}^{-1}$ and $810 \mathrm{~cm}^{-1}$, respectively, which can be attributed with certainty to the asymmetric stretching $\mathrm{v}_{3}\left(\mathrm{AsO}_{4}\right)$ modes.
\end{abstract}

Keywords: magnesium cesium arsenate hexahydrate; cubic; infrared spectra; Raman spectra; difference spectrum

\section{ИНФРАЦРВЕНИ И РАМАНСКИ СПЕКТРИ НА КУБИЧНАТА ФОРМА НА МАГНЕЗИУМ ЦЕЗИУМ АРСЕНАТ ХЕКСАХИДРАТ}

Фуриеовите трансформирани инфрацрвени (FT-IR) спектри снимени на собна температура (RT) и на температурата на вриење на течен азот (LNT), како и раманските спектри снимени на собна температура за кубичен полиморф на магнезиум цезиум арсенат хексахидрат $\left(\mathrm{MgCsAsO}_{4} \cdot 6 \mathrm{H}_{2} \mathrm{O}\right)$ и на неговите делумно деутерирани аналози, беа интерпретирани вклучувајќ ги нормалните модови на молекулите вода, на арсенатните јони и на либрациите на молекулите вода. Спектралните карактеристики на $\mathrm{MgCsAsO}_{4} \cdot 6 \mathrm{H}_{2} \mathrm{O}$ беа споредувани со кубичната форма на фосфатниот аналог. Беше најдена голема спектрална сличност помеѓу двете изоструктурни соли, освен во делот кој се должи на разликите поради природата на анјоните $\left(\mathrm{AsO}_{4}{ }^{3-}\right.$ vs $\left.\mathrm{PO}_{4}{ }^{3-}\right)$. Спектроскопските податоци за неспрегнатите OD валентни модови на матрично изолираните HDO молекули покажуваат дека водородните врски формирани во арсенатната сол се посилни од оние во фосфатниот аналог. Во раманскиот спектар на протонираното соединение, во областа на валентните вибрации на јоните на $\mathrm{AsO}_{4}{ }^{3-}$, е забележана само една многу интензивна лента на $811 \mathrm{~cm}^{-1}$, која е нечувствителна на деутерирање. Во согласност со очекувањата, во истиот спектрален опсег во инфрацрвените спектри на протонираното и на високодеутерираното соединение се појавува една лента на 792 
$\mathrm{cm}^{-1}$ и $810 \mathrm{~cm}^{-1}$ соодветно, која може со сигурност да се припише на антисиметрични валентни модови $v_{3}\left(\mathrm{AsO}_{4}\right)$.

Клучни зборови: магнезиум цезиум арсенат хексахидрат; кубичен; инфрацрвени спектри; рамански спектри; диферентен спектар

\section{INTRODUCTION}

Struvite-type and related compounds with the formula $\mathrm{M}^{\mathrm{I}} \mathrm{M}^{\mathrm{II}} \mathrm{XO}_{4} \cdot 6 \mathrm{H}_{2} \mathrm{O}\left(\mathrm{M}^{\mathrm{I}}=\mathrm{NH}_{4}, \mathrm{~K}, \mathrm{Rb}, \mathrm{Cs}\right.$ and $\mathrm{Tl} ; \mathrm{M}^{\mathrm{II}}=\mathrm{Mg}$, Co and $\mathrm{Ni} ; \mathrm{X}=\mathrm{P}$ and As) have been studied in our lab for many years, mainly from a spectroscopic point of view [1-14]. Generally, our investigations have been focused on the members of the struvite-type family belonging to the orthorhombic space group $P m n 2_{1}\left(C_{2 v}{ }^{7}\right)$ [1-6, $8,10]$. Cesium-containing salts, however, crystallize in two other crystal systems, cubic and hexagonal $[7,9,15,16]$. The building units in the three structural forms are the same: $\left[\mathrm{M}^{\mathrm{II}}\left(\mathrm{H}_{2} \mathrm{O}\right)_{6}\right]^{2+}$ cations and $\mathrm{XO}_{4}{ }^{3-}$ anions are connected by hydrogen bonds, forming a three-dimensional framework, while the monovalent $\mathrm{M}^{\mathrm{I}}$ cations are located in the voids of this arrangement. However, the difference in the space group symmetries of the three structural forms imposes different sequences of the close-packed layers of $\mathrm{M}^{\mathrm{I}},\left[\mathrm{M}^{\mathrm{II}}\left(\mathrm{H}_{2} \mathrm{O}\right)_{6}\right]^{2+}$ and $\mathrm{XO}_{4}{ }^{3-}$ units, and these structural features have been described by Massa et al. [15].

In our previous studies [7, 9] we have analyzed the vibrational spectra of the two forms of $\mathrm{MgCsPO}_{4} \cdot 6 \mathrm{H}_{2} \mathrm{O}$, hexagonal and cubic. Continuing the systematic study of the struvite series, here, we report the results from the detailed analysis of the infrared spectra recorded at room temperature (RT) and at the boiling temperature of liquid nitrogen (LNT), as well as the Raman spectra recorded at room temperature for its arsenate analogue $\left(\mathrm{MgCsAsO}_{4} \cdot 6 \mathrm{H}_{2} \mathrm{O}\right)$ and those of its deuterated analogues. To the best of our knowledge, the vibrational spectra of the deuterated analogues of this compound have not been studied or reported.

So far, a cubic form of $\mathrm{MgCsAsO}_{4} \cdot 6 \mathrm{H}_{2} \mathrm{O}$ is only known in contrast to the dimorphic phosphate analogue. $\mathrm{MgCsAsO}_{4} \cdot 6 \mathrm{H}_{2} \mathrm{O}$ crystallizes in the cubic space group $F-43 m\left(T^{2}{ }_{\mathrm{d}}\right)$ with $Z=4$ [17]. In this context, the investigated compound is not, exactly speaking, isomorphous to struvite $\left(\mathrm{MgNH}_{4} \mathrm{PO}_{4} \cdot 6 \mathrm{H}_{2} \mathrm{O}\right)$ as the general title of the series of papers implies. This compound is isostructural with the cubic form of $\mathrm{MgCsPO}_{4} \cdot 6 \mathrm{H}_{2} \mathrm{O}$ [15] and $\mathrm{FeCsPO}_{4} \cdot 6 \mathrm{H}_{2} \mathrm{O}$ [18]. $\mathrm{Cs}^{+}, \mathrm{Mg}^{2+}$ and $\mathrm{AsO}_{4}{ }^{3-}$ in the unit cell lie on the sites with $T_{\mathrm{d}}$ symmetry, while water molecules occupy sites with $C_{2 \mathrm{v}}$ sym- metry. There is one crystallographic type of water molecule that is trigonally coordinated and forms strong hydrogen bonds with the oxygen atoms from the arsenate anions $(\mathrm{O} 1 \ldots \mathrm{O} 2)$. With a distance of $260.5 \mathrm{pm}$, these hydrogen bonds are shorter than those in the phosphate analogue (264.9 $\mathrm{pm})$. What makes this system interesting and remarkable is the fact that the crystallographic symmetry of both water molecules and arsenate ions in the structure is the highest symmetry possible for their point groups, $C_{2 \mathrm{v}}$ and $T_{\mathrm{d}}$, respectively. Also, the point group, which is isomorphous to the factor group and space group, has a $T_{\mathrm{d}}$ symmetry as arsenate ions. Such structural features of retaining the highest crystallographic symmetry of both water molecules and arsenate ions are very rare in crystalline hydrates and deserves a thorough study from a spectroscopic point of view.

\section{EXPERIMENTAL}

The synthesis of $\mathrm{CsMgAsO}_{4} \cdot 6 \mathrm{H}_{2} \mathrm{O}$ was performed at room temperature in a $50 \mathrm{ml}$ laboratory beaker by mixing $10 \mathrm{ml}$ of each of the solutions according to the following order. At the beginning,

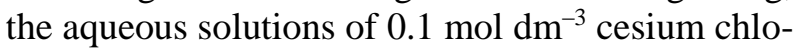
ride and $0.3 \mathrm{~mol} \mathrm{dm}^{-3}$ disodium hydrogen arsenate were mixed. Then, under constant stirring, a 0.1 mol dm ${ }^{-3}$ solution of magnesium sulphate was added in small volume portions and a precipitation was observed. The $\mathrm{pH}$ value of this solution was 7 . At the end, with continues stirring, $0.1 \mathrm{~mol} \mathrm{dm}^{-3}$ aqueous solutions of sodium hydroxide were added drop-wise up to a $\mathrm{pH}$ value of 9 . The beaker with the precipitate and mother liquor was sealed with paraffin foil and left at room temperature (about $20^{\circ} \mathrm{C}$ ). After the overnight recrystallization time, the precipitate was separated by vacuum filtration, washed with water, and dried at room temperature.

Partially deuterated analogues were obtained by employing the same general procedure, but using $\mathrm{H}_{2} \mathrm{O}-\mathrm{D}_{2} \mathrm{O}$ mixtures as solvents with appropriate compositions. The highest content of deuterium in the samples was achieved using pure $\mathrm{D}_{2} \mathrm{O}$.

Pressed $\mathrm{KBr}$ disks and mulls were used for recording the infrared spectra at both RT and LNT. FT-IR spectra were obtained using a Perkin-Elmer System 2000 infrared interferometer. The variable- 
temperature cell P/N 21525 (Graseby Specac) was used for obtaining the low-temperature spectra. To get an adequate signal-to-noise ratio, 64 scans at LNT were collected and averaged, while 32 scans were sufficient at RT. All measurements were performed with a resolution of $2 \mathrm{~cm}^{-1}$. GRAMS ANALYST 2000 [19] and GRAMS 32 [20] packages were used for spectra acquisition and management.

A micro-Raman spectrometer LabRam 300 (Horiba Jobin-Yvon) was used for recording the RT Raman spectra of the studied compound and its deuterated analogues at room temperature. It was equipped with two lasers: a He-Ne laser operating at $633 \mathrm{~nm}(6 \mathrm{~mW}$ power on the sample) and a double frequency Nd:YAG laser at $532 \mathrm{~nm}(5 \mathrm{~mW}$ power at the sample). A microscope Olympus MPlanN with a magnification of 50 and 100 was used. The spectra were recorded with a resolution of $2 \mathrm{~cm}^{-1}$ and acquisition times between 10 and 40 s with 15-30 scans. The GRAMS ANALYST 2000 software package was used for spectra acquisition [19] and GRAMS 32 [20] was used for spectra management.

To check the identity of the synthesized products, X-ray diffractograms of the powder samples were obtained and analyzed, which corresponded to that reported for cubic $\mathrm{MgCsAsO}_{4} \cdot 6 \mathrm{H}_{2} \mathrm{O}$ (PDF-98-026-0150) (Fig. 1). The X-ray powder diffraction (XRPD) measurements were conducted on a Rigaku Ultima IV powder X-ray diffractometer $\left(\mathrm{CuK}_{\alpha}\right.$ radiation). Each studied sample was manually dispersed over a silicon sample plate, and the data was collected at room temperature on a D/tex detector in the $2 \theta$ range of $5-80^{\circ}$ (scan rate $=2 \% / \mathrm{min}$ ). $\mathrm{CuK} \alpha$ radiation was obtained from a generator set at $40 \mathrm{kV}$ and a current of $40 \mathrm{~mA}$.

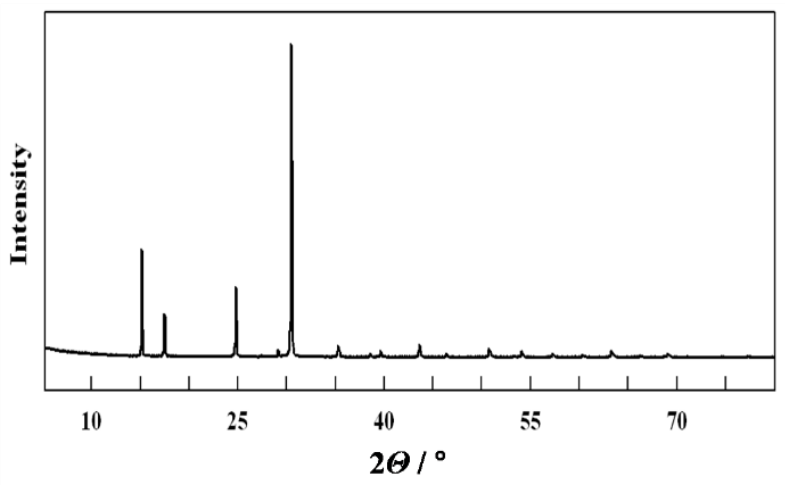

Fig. 1. Scattered intensities as a function of the diffraction angle in the cubic form of $\mathrm{MgCsAsO}_{4} \cdot 6 \mathrm{H}_{2} \mathrm{O}$

\section{RESULTS AND DISCUSSION}

The infrared spectra of the studied compound, the cubic form of $\mathrm{MgCsAsO}_{4} \cdot 6 \mathrm{H}_{2} \mathrm{O}$, recorded at RT and at LNT and the Raman spectrum recorded at RT are given in Figure 2 and Figure 3. These spectra are very similar to those of $\mathrm{MgNH}_{4} \mathrm{AsO}_{4} \cdot 6 \mathrm{H}_{2} \mathrm{O}$ [5] and $\mathrm{MgKAsO}_{4} \cdot 6 \mathrm{H}_{2} \mathrm{O}$ [10], although they crystallize in the orthorhombic crystal system.

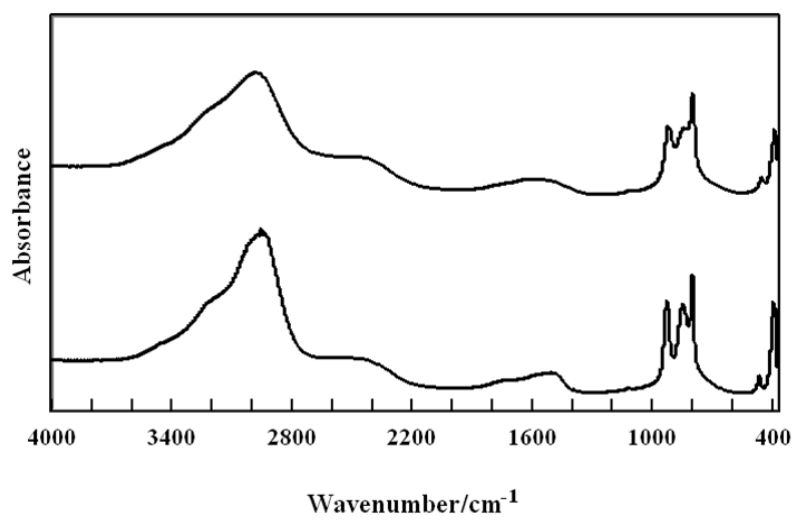

Fig. 2. IR spectra of the cubic form of $\mathrm{MgCsAsO}_{4} \cdot 6 \mathrm{H}_{2} \mathrm{O}$ recorded at LNT (lower curve) and at RT (upper curve) (offset spectra are presented)

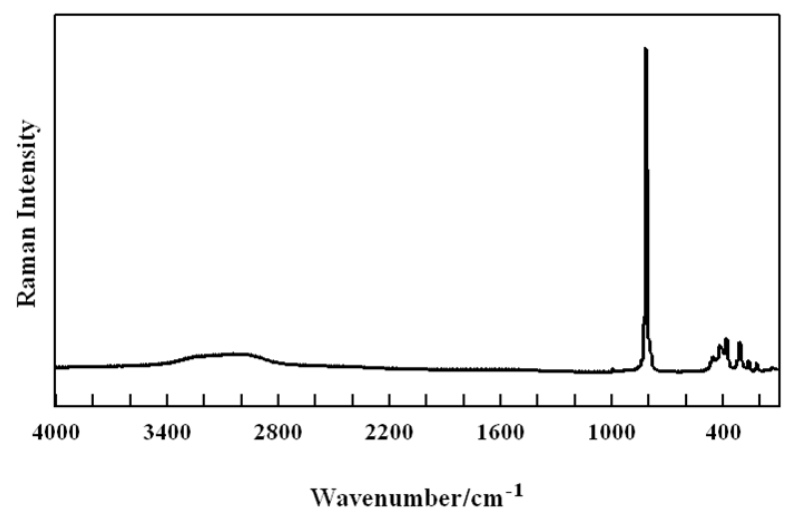

Fig. 3. Raman spectra of the cubic form of $\mathrm{MgCsAsO}_{4} \cdot 6 \mathrm{H}_{2} \mathrm{O}$ recorded at RT

The assignment of the IR and Raman bands in the spectra of the cubic form of $\mathrm{MgCsAsO}_{4} \cdot 6 \mathrm{H}_{2} \mathrm{O}$ and its almost completely deuterated analogue to specific vibrational modes is given in Table 1 . 
T able 1

Assignments of the vibrational bands in the IR spectra and Raman spectra of the cubic form of $\mathrm{MgCsAs} \mathrm{O}_{4} \cdot 6 \mathrm{H}_{2} \mathrm{O}$ with their estimated intensities ${ }^{a}$

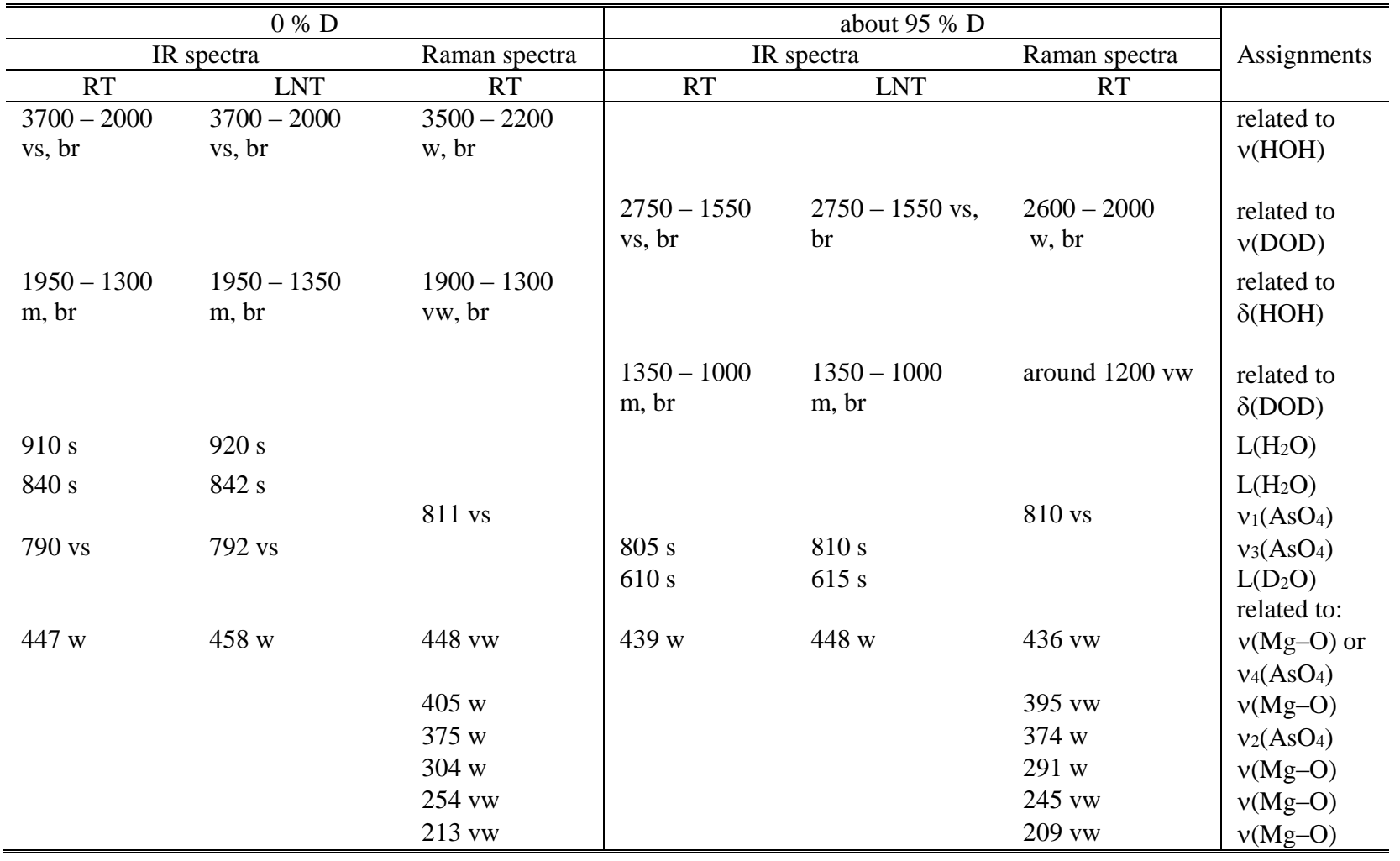

aEstimated intensities: $\mathrm{s}$ - strong; $\mathrm{m}$ - medium; w - weak; v - very; sh - shoulder; br - broad; $v$ - stretching; $\delta$ - bending; L - libration

\subsection{Internal vibrations of the water molecules}

As mentioned above, there is only one crystallographic type of water molecule in the structure of the studied compound that occupies a position with $C_{2 \mathrm{v}}$ symmetry, and following the factor-group analysis for the cubic form of $\mathrm{MgCsPO}_{4} \cdot 6 \mathrm{H}_{2} \mathrm{O}$ [9] in the absence of a correlation field, three infrared active and three Raman active internal modes $\left(2 A_{1}\right.$ $\left.+B_{1}\right)$ are expected. Under the influence of the correlation field, each $A_{1}$ mode splits in $\left(\mathrm{A}_{1}+E+F_{2}\right)$ modes, while $B_{1}$ mode splits in $\left(F_{1}+F_{2}\right)$ modes. The components with $F_{2}$ symmetry are infrared and Raman active. Those with $A_{1}$ and $E$ symmetry are only Raman active, while the $F_{1}$ mode is silent. This means that in the latter case the number of expected bands in the infrared spectrum would still be three, whereas seven bands would be expected in the Raman spectrum.

\subsubsection{Stretching vibrations of the water molecules}

In the region of the stretching modes in the infrared spectra, a broad asymmetric and deuteration-sensitive band appeared between 3700 and $2000 \mathrm{~cm}^{-1}$ (Fig. 4). A broad band with much smaller intensity was found in the Raman spectrum (Fig. 3). The appearance of such a broad and intensive band is characteristic for all IR spectra of struvite, its analogues, and related compounds [114], irrespective of both types of the crystal system in which these compounds crystallize (orthorhombic, cubic or hexagonal) and the number of the crystallographically different water molecules available in their structures (one, two or four water molecules in cubic, hexagonal, and orthorhombic crystal structures, respectively). In fact, this is directly related to the existence of strong hydrogen bonds in the structures of these systems.

Having in mind that the one crystallographic type of water molecule lays on the site with $C_{2 \mathrm{v}}$ symmetry, only one band is expected to appear in the region of the isotopically isolated HDO molecules. In the difference IR spectrum of slightly deuterated analogues (approximately $4 \%$ D), one intense band appeared at $2249 \mathrm{~cm}^{-1}$, but another one appeared around $2160 \mathrm{~cm}^{-1}$ (Fig. 5). This feature is very similar to that observed in the cubic form of $\mathrm{MgCsPO}_{4} \cdot 6 \mathrm{H}_{2} \mathrm{O}$ [9], but in the arsenate salt the intensity of the low-numbered band was higher than that found for the corresponding band in the spectrum of the phosphate salt. 


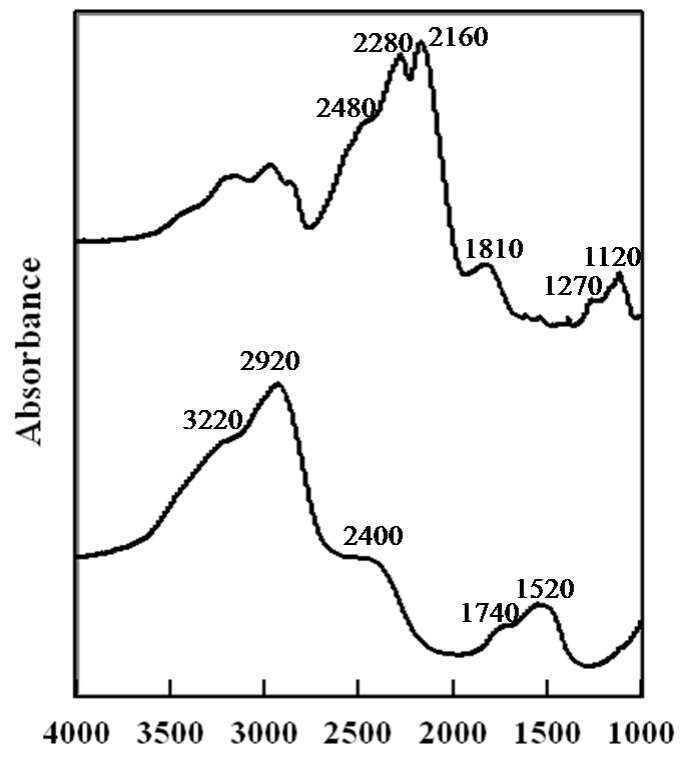

Wavenumber $/ \mathrm{cm}^{-1}$

Fig. 4. Infrared spectra of the cubic form of $\mathrm{MgCsAsO}_{4} \cdot 6 \mathrm{H}_{2} \mathrm{O}$ (lower curve) and its almost completely deuterated analogue (upper curve) recorded at LNT in the region of the OH/OD stretching vibrations and $\mathrm{HOH} / \mathrm{DOD}$ bending vibrations (offset spectra are presented)

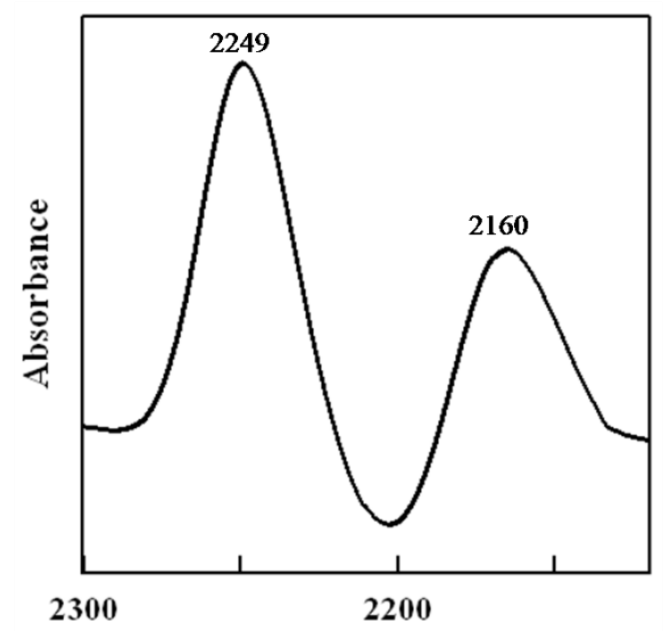

Wavenumber $/ \mathrm{cm}^{-1}$

Fig. 5. Difference IR spectra recorded at LNT in the region of the $v(\mathrm{OD})$ vibrations obtained by subtracting the spectrum of the protiated compound (cubic form of $\mathrm{MgCsAsO}_{4} \cdot 6 \mathrm{H}_{2} \mathrm{O}$ ) from the spectrum of the analogue with low deuterium content $(\approx 4 \% \mathrm{D})$

The high-numbered band is unequivocally attributed to the uncoupled OD stretching mode of the matrix-isolated HDO molecules. The comparison shows that this mode appears in $\mathrm{MgCsAsO}_{4} \cdot 6 \mathrm{H}_{2} \mathrm{O}$ at lower wavenumbers than in the cubic form of $\mathrm{MgCsPO}_{4} \cdot 6 \mathrm{H}_{2} \mathrm{O}\left(2249 \mathrm{~cm}^{-1}\right.$ vs $2260 \mathrm{~cm}^{-1}$ [9]), and this is a spectroscopic evidence for the formation of stronger hydrogen bonds in the arsenate than in phosphate salt. This fact is in accordance with both the shorter hydrogen bond distance in arsenate than in the phosphate salt ( $260.5 \mathrm{pm} v \mathrm{~s} 264.9 \mathrm{pm})$ and the stronger hydrogen-bond acceptor ability of $\mathrm{AsO}_{4}{ }^{3-}$ compared to $\mathrm{PO}_{4}{ }^{3-}$ [21]. Regarding the second band in this region, in the case of the cubic form of $\mathrm{MgCsPO}_{4} \cdot 6 \mathrm{H}_{2} \mathrm{O}$, we have assigned it as a result of second-order transitions involving motions of the HDO molecules, i.e. a combination of $\delta(\mathrm{HDO})$ and some HDO libration [9]. Given that the studied compound is isostructural with the $\mathrm{cu}$ bic form of $\mathrm{MgCsPO}_{4} \cdot 6 \mathrm{H}_{2} \mathrm{O}$, meaning it has practically identical structural features, we can use the analogous interpretation for the appearance of the second band in this case as well.

\subsubsection{Bending vibrations of the water molecules}

In the region of the $\mathrm{HOH}$ bending modes in the infrared spectra, one can see a complex and deuteration-sensitive band with visible maxima around $1745 \mathrm{~cm}^{-1}, 1550 \mathrm{~cm}^{-1}$, and $1480 \mathrm{~cm}^{-1}$ (Fig. 4 ), and again the spectral picture is very similar to that obtained for the cubic form of $\mathrm{MgCsPO}_{4} \cdot 6 \mathrm{H}_{2} \mathrm{O}$ [9]. In the spectrum of the analogue with the highest deuterium content, these bands appeared at $1262 \mathrm{~cm}^{-1}, 1161 \mathrm{~cm}^{-1}$, and 1117 $\mathrm{cm}^{-1}$. It should be mentioned that factor group analysis [9] predicts a single band in both cases: absence or presence of correlation field effects. As in the case of the other studied struvite compounds and related compounds [1-10, 13], this complex band/s can be attributed to the second order transitions, interactions of the Fermi resonance type (interactions of overtones of lower frequency modes with $\delta(\mathrm{HOH})$ vibrations), or to coupling with low frequency modes of the lattice.

The deuteration-sensitive bands that appear at around $2400 \mathrm{~cm}^{-1}$ in the spectrum of the protiated compound and the corresponding bands in the spectrum of the compound with the highest deuterium content are found at around $1800 \mathrm{~cm}^{-1}$, have been assigned as result of second-order transitions between $\mathrm{H}_{2} \mathrm{O}$ bendings and some water librational modes, as in the case of the other struvites and related compounds $[1-10,13]$.

\subsection{External vibrations of the water molecules}

Following the factor-group analysis [9], only one band for each of the rocking and wagging mode is expected in the infrared spectrum (twisting mode is IR inactive), whereas one band for each of 
the three librational modes is expected in the Raman spectra. With respect to the stretching $v(\mathrm{Mg}-\mathrm{O})$ mode, without a correlation field the theory gives one band in the Raman spectra and three bands considering crystal field splitting. On the other hand, only one band from the $v(\mathrm{Mg}-\mathrm{O})$ modes is predicted in the infrared spectra, even in presence of the resonance field.

The assignment of the bands due to librational modes of the water molecules in the vibrational spectra of crystal hydrates has been carried out by many authors [21-24]. In spite of that, no specific certain are suggested for their exact determination. Even so, the method of the $\mathrm{H}_{2} \mathrm{O} / \mathrm{D}_{2} \mathrm{O}$ and $\mathrm{H}_{2} \mathrm{O} / \mathrm{HDO}$ isotopic shift of the bands due to librations in the vibrational spectra [25, 26], as well as the method based on measurement of the intensities of the bands due to librational modes of the water molecules [27, 28], have been demonstrated as most relevant.

Assignment of the bands from librations of water molecules has been carried out according to their shape, intensity, negative temperature coefficient, and the changes observed at different degrees of deuteration. Comparing the infrared spectra of the protiated compound recorded at RT and LNT (Fig. 6), as well as the spectra of the partially deuterated analogues (Fig. 7), the bands at $920 \mathrm{~cm}^{-1}$ and $842 \mathrm{~cm}^{-1}$ can be, with high certainty, attributed to librations of water molecules. The high frequencies of the $\mathrm{H}_{2} \mathrm{O}$ librations are in accordance with the structural data for existence of strong hydrogen bonds involving water molecules. We have assigned the corresponding bands observed at similar frequencies for the cubic form of $\mathrm{MgCsPO}_{4} \cdot 6 \mathrm{H}_{2} \mathrm{O}$ as a result of the rocking (higher frequency one) and wagging (lower frequency one) modes [9]. In the IR spectrum of the analog with the highest deuterium content, two bands were expected due to librations of the $\mathrm{D}_{2} \mathrm{O}$ molecules. However, we were intrigued to observe only one new intensive band at $615 \mathrm{~cm}^{-1}$ in the spectrum that can be assigned to $\mathrm{D}_{2} \mathrm{O}$ librations. The calculated factor of the $\mathrm{H}_{2} \mathrm{O} / \mathrm{D}_{2} \mathrm{O}$ isotopic shift of the bands from librations was 1.49 (rather high value) and 1.37, respectively. This clearly indicates that the $\mathrm{H}_{2} \mathrm{O}$ analogue of the band at $615 \mathrm{~cm}^{-1}$ is the one at $842 \mathrm{~cm}^{-1}$. So, there is no visible band that would be a result of $\mathrm{D}_{2} \mathrm{O}$ rocking modes. It should be noted that such a band has been observed in the spectrum of the analogue of the cubic form of $\mathrm{MgCsPO}_{4} \cdot 6 \mathrm{H}_{2} \mathrm{O}$ with the highest deuterium content, but this band is with very low intensity [9].

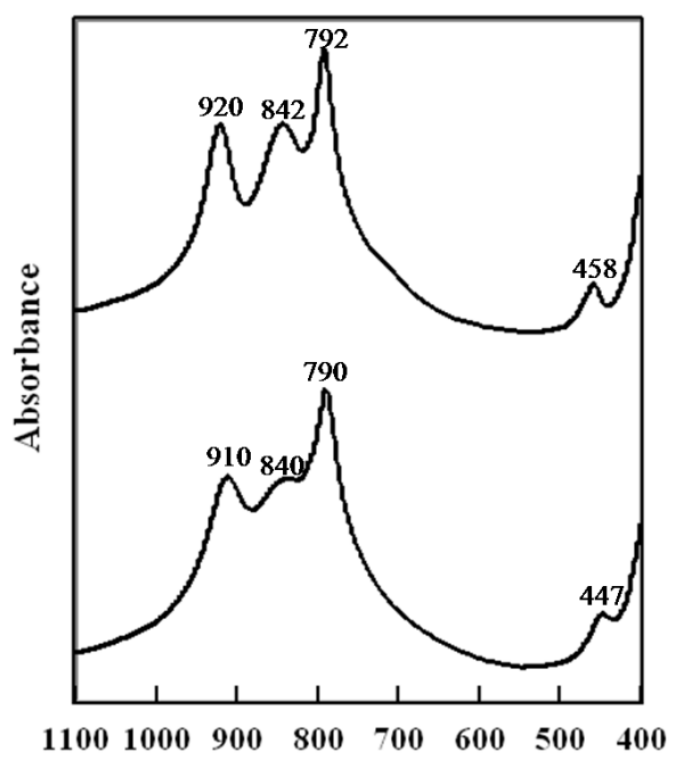

Wavenumber $/ \mathrm{cm}^{-1}$

Fig. 6. IR spectra of the cubic form of $\mathrm{MgCsASO}_{4} \cdot 6 \mathrm{H}_{2} \mathrm{O}$ recorded at RT (lower curve) and LNT (upper curve) in the region of the $\mathrm{HOH}$ external and $\mathrm{AsO}_{4}$ internal vibrations (offset spectra are presented)

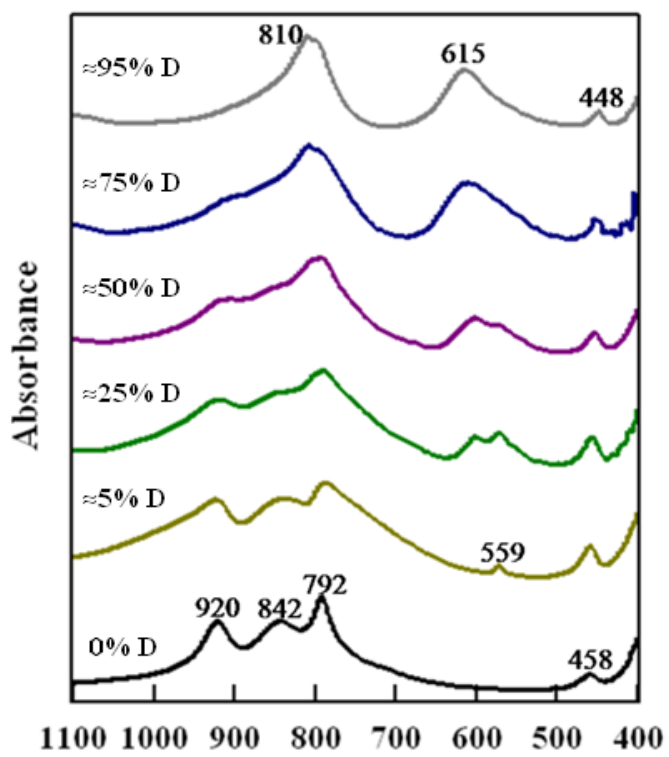

Wavenumber $/ \mathrm{cm}^{-1}$

Fig. 7. IR spectra of partially and nearly fully deuterated analogues of the cubic form of $\mathrm{MgCsAsO}_{4} \cdot 6 \mathrm{H}_{2} \mathrm{O}$ recorded at LNT in the region of the $\mathrm{HOH}$ external and $\mathrm{AsO}_{4}$ internal vibrations (the content of deuterium increased from bottom to top; offset spectra are presented)

On the other hand, in the spectra of the partially deuterated analogues (Fig. 7), the band at 571 $\mathrm{cm}^{-1}$ can be assigned as a result of HDO librations. Such bands have not been observed in the corre- 
sponding spectra of the cubic form of $\mathrm{MgCsPO}_{4} \cdot 6 \mathrm{H}_{2} \mathrm{O}$ [9], probably because of the fact that there is a band at $559 \mathrm{~cm}^{-1}$ in the phosphate compound as a result of the $v_{4}\left(\mathrm{PO}_{4}\right)$ mode that may overlap these bands. In the Raman spectra of the protiated compound and the spectra of the partially deuterated analogues, similar for the cubic form of $\mathrm{MgCsPO}_{4} \cdot 6 \mathrm{H}_{2} \mathrm{O}$ [9], there is no band with visible intensity in the region of the librational modes (Fig. 8).

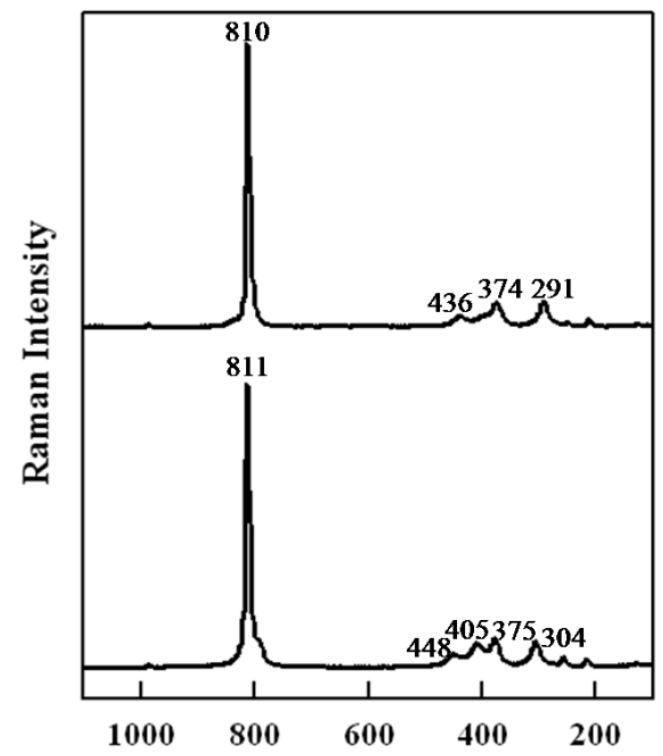

Wavenumber $/ \mathrm{cm}^{-1}$

Fig. 8. Raman spectra of the cubic form of $\mathrm{MgCsAsO}_{4} \cdot 6 \mathrm{H}_{2} \mathrm{O}$ (lower curve) and its almost completely deuterated analogue (upper curve) recorded at $\mathrm{RT}$ in the region of the $\mathrm{HOH}$ external and $\mathrm{AsO}_{4}$ internal vibrations (offset spectra are presented)

\subsection{Vibrations of the arsenate ions}

As previously mentioned, the arsenate ions in the structure of the studied compound occupy sites with $T_{\mathrm{d}}$ symmetry, and the point group that is isomorphous with the factor group of the space group also has $T_{\mathrm{d}}$ symmetry. This means that the correlation field has no effect on the vibrations of the arsenate ions. Hence, in the infrared spectrum one band for each $v_{3}$ and $v_{4}$ mode of the arsenate ions is expected, while in the Raman spectra four bands are expected to appear (one for each $v_{1}, v_{2}$, $v_{3}$ and $v_{4}$ mode).

In the Raman spectrum of the protiated compound, only one very intensive band at 811 $\mathrm{cm}^{-1}$ is observed in the region of the stretching vibrations of $\mathrm{AsO}_{4}{ }^{3-}$ ion, and it is insensitive to deuteration $\left(810 \mathrm{~cm}^{-1}\right.$ in the spectrum of the highly deuterated sample) (Fig. 8). Therefore, it is assigned to the symmetric stretching $v_{1}\left(\mathrm{AsO}_{4}\right)$ mode (Table 1). In accordance with the expectation, one band appears in the same spectral range in the infrared spectra of the protiated and highly deuterated sample at $792 \mathrm{~cm}^{-1}$ and $810 \mathrm{~cm}^{-1}$, respectively (Fig. 7), which can be attributed with certainty to the asymmetric stretching $v_{3}\left(\mathrm{AsO}_{4}\right)$ modes.

It is interesting to note that in the infrared spectra of the deuterated analogues with 5, 25 and $50 \% \mathrm{D}$, the band from the $v_{3}\left(\mathrm{AsO}_{4}\right)$ mode is additionally split, similar to that already found in the cubic form of $\mathrm{MgCsPO}_{4} \cdot 6 \mathrm{H}_{2} \mathrm{O}$ [9]. We have explained this phenomenon for the phosphate analogue as originating from the $v_{3}\left(\mathrm{PO}_{4}\right)$ modes that are in the vicinity of $\mathrm{HDO}$ or $\mathrm{D}_{2} \mathrm{O}$ molecules to which the phosphate oxygens serve as proton acceptors. In this way, in the course of the H/D substitution, the ideal symmetric phosphate anions "see" an environment with $\mathrm{H}$ statistically substituted by D. This destroys the ideal $T_{\mathrm{d}}$ symmetry of that environment and the lower symmetry of the environment is back-reflected on the symmetry of the phosphate anions, which now vibrate in a force field that is not of $T_{\mathrm{d}}$ symmetry anymore.

The band at $458 \mathrm{~cm}^{-1}$ (Fig. 7) in the infrared spectrum of the studied compound can be attributed to the asymmetric bending $v_{4}\left(\mathrm{AsO}_{4}\right)$ modes or to $\mathrm{Mg}-\mathrm{O}$ vibrations. In fact, with increasing deuterium content in the crystals (Fig. 7), this band is shifted to lower frequencies and is observed at 448 $\mathrm{cm}^{-1}$ in the spectrum of the compound with the highest deuterium content. The appearance of a single band in this region, the low frequency ratio of the $\mathrm{H}_{2} \mathrm{O} / \mathrm{D}_{2} \mathrm{O}$ isotopic shift (1.022), together with the fact that no band from the $v_{2}\left(\mathrm{AsO}_{4}\right)$ modes is expected in the infrared spectrum, confirms our interpretation. A few deuteration-sensitive bands are observed in the Raman spectrum of the protiated compound at $448 \mathrm{~cm}^{-1}, 405 \mathrm{~cm}^{-1}, 375 \mathrm{~cm}^{-1}, 304$ $\mathrm{cm}^{-1}, 254 \mathrm{~cm}^{-1}$ and $213 \mathrm{~cm}^{-1}$ (Fig. 8). For the analogue with the highest deuterium content, the corresponding bands are at $436 \mathrm{~cm}^{-1}, 395 \mathrm{~cm}^{-1}, 374$ $\mathrm{cm}^{-1}, 291 \mathrm{~cm}^{-1}, 245 \mathrm{~cm}^{-1}$ and $209 \mathrm{~cm}^{-1}$ (Fig. 8). The band at $448 \mathrm{~cm}^{-1}$ most probably originates from $v_{4}\left(\mathrm{AsO}_{4}\right)$ modes. The band at $375 \mathrm{~cm}^{-1}$ is practically deuteration-insensitive and can be assigned to symmetric bending $v_{2}\left(\mathrm{AsO}_{4}\right)$ modes, while some of the others can be related to the $\mathrm{Mg}-$ $\mathrm{O}$ modes.

\section{CONCLUSION}

The present paper provides new data on the infrared and Raman spectra of the cubic form of 
$\mathrm{MgCsAsO}_{4} \cdot 6 \mathrm{H}_{2} \mathrm{O}$. The IR spectra of cesium magnesium arsenate hexahydrate, as well as those of a series of its partially deuterated analogues, were recorded at room temperature and at the boiling temperature of liquid nitrogen and analyzed with a focus on spectra-structure correlations. The vibrational spectra of $\mathrm{MgCsAsO}_{4} \cdot 6 \mathrm{H}_{2} \mathrm{O}$ was compared with those of the cubic form of the phosphate analogue. Besides the obvious difference in the nature of the arsenate and phosphate anions, the spectral features of the two salts were very similar, thus confirming their isostructurality. Analogous to the cubic form of $\mathrm{MgCsPO}_{4} \cdot 6 \mathrm{H}_{2} \mathrm{O}$, in the lowtemperature difference spectrum of $\approx 4 \%$ deuterated arsenate salt, two bands were found out of the expected bands due to the uncoupled O-D stretching modes of the isotopically isolated HDO molecules. Regarding the second band observed at the two salts in this region, we have assigned it as a result of second-order transitions involving motions of the HDO molecules, i.e. a combination of $\delta(\mathrm{HDO})$ and some HDO libration. By comparing the IR spectra in the region of external vibrations of water molecules and internal modes of the arsenate ions of the protiated compound recorded at RT (room temperature) and at LNT (liquid nitrogen temperature) and those in the series of the partially deuterated analogues, an assignment of bands due to librations of water molecules, $v_{3}\left(\mathrm{AsO}_{4}\right)$, $v_{1}\left(\mathrm{AsO}_{4}\right)$ and $v_{2}\left(\mathrm{AsO}_{4}\right)$ modes, was proposed.

\section{REFERENCES}

[1] V. Stefov, B. Šoptrajanov, F. Spirovski, I. Kuzmanovski, H. D. Lutz, B. Engelen, Infrared and Raman spectra of magnesium ammonium phosphate hexahydrate (struvite) and its isomorphous analogues. I. Spectra of protiated and partially deuterated magnesium potassium phosphate hexahydrate, J. Mol. Struct., 689, 1-10 (2004). DOI: https://doi.org/10.1016/j.molstruc.2003.08.019

[2] B. Šoptrajanov, V. Stefov, H. D. Lutz, B. Engelen, Infrared and Raman spectra of magnesium ammonium phosphate hexahydrate (struvite) and its isomorphous analogues. II. The $\mathrm{O}-\mathrm{H} / \mathrm{N}-\mathrm{H}$ streching region, in: $\mathrm{E}$. Faulques, D. Perry, A. Yeremenko (Eds.), NATO Science Volume: Spectroscopy of Emerging Materials, Kluwer, Dordrecht, 2004, p. 299-308.

[3] V. Stefov, B. Šoptrajanov, I. Kuzmanovski, H. D. Lutz, B. Engelen, Infrared and Raman spectra of magnesium ammonium phosphate hexahydrate (struvite) and its isomorphous analogues. III. Spectra of protiated and partially deuterated magnesium ammonium phosphate hexahydrate, J. Mol. Struct., 752, 60-67 (2005). DOI: https://doi.org/10.1016/j.molstruc.2005.05.040

[4] A. Cahil, M. Najdoski, V. Stefov, Infrared and Raman spectra of magnesium ammonium phosphate hexahydrate (struvite) and its isomorphous analogues. IV. FTIR spectra of protiated and partially deuterated nickel am- monium phosphate hexahydrate and nickel potassium phosphate hexahydrate, J. Mol. Struct., 834-836, 408413 (2007).

DOI: https://doi.org/10.1016/j.molstruc.2006.11.049

[5] V. Stefov, B. Šoptrajanov, M. Najdoski, B. Engelen, H. D. Lutz, Infrared and Raman spectra of magnesium ammonium phosphate hexahydrate (struvite) and its isomorphous analogues. V. Spectra of protiated and partially deuterated magnesium ammonium arsenate hexahydrate (arsenstruvite), J. Mol. Struct., 872, 87-92 (2008). DOI: https://doi.org/10.1016/j.molstruc.2007.02.017

[6] A. Cahil, B. Šoptrajanov, M. Najdoski, H. D. Lutz, B. Engelen, V. Stefov, Infrared and Raman spectra of magnesium ammonium phosphate hexahydrate (struvite) and its isomorphous analogues. VI. FT-IR spectra of isomorphously isolated species. $\mathrm{NN}_{4}{ }^{+}$ions isolated in $\mathrm{MKPO}_{4} \cdot 6 \mathrm{H}_{2} \mathrm{O}(\mathrm{M}$ $=\mathrm{Mg} ; \mathrm{Ni}$ ) and $\mathrm{PO}_{4}{ }^{3-}$ ions isolated in $\mathrm{MgNH}_{4} \mathrm{AsO}_{4} \cdot 6 \mathrm{H}_{2} \mathrm{O}, J$. Mol. Struct., 876, 255-259 (2008).

DOI: https://doi.org/10.1016/j.molstruc.2007.06.023

[7] V. Stefov, A. Cahil, B. Šoptrajanov, M. Najdoski, F. Spirovski, B. Engelen, H. D. Lutz, V. Koleva, Infrared and Raman spectra of magnesium ammonium phosphate hexahydrate (struvite) and its isomorphous analogues. VII. Spectra of protiated and partially deuterated hexagonal magnesium caesium phosphate hexahydrate, $J$. Mol. Struct., 924-926, 100-106 (2009).

DOI: https://doi.org/10.1016/j.molstruc.2008.12.009

[8] B. Šoptrajanov, A. Cahil, M. Najdoski, V. Koleva, V. Stefov, Infrared and Raman spectra of magnesium ammonium phosphate hexahydrate (struvite) and its isomorphous analogues. VIII. Spectra of protiated and partially deuterated magnesium rubidium phosphate hexahydrate and magnesium thallium phosphate hexahydrate, Acta Chim. Slov., 58, 478-484 (2011).

[9] V. Stefov, Z. Abdija, M. Najdoski, V. Koleva, V. M. Petruševski, T. Runčevski, R. E. Dinnebier and B. Šoptrajanov, Infrared and Raman spectra of magnesium ammonium phosphate hexahydrate (struvite) and its isomorphous analogues. IX. Spectra of protiated and partially deuterated cubic magnesium caesium phosphate hexahydrate, Vib. Spectrosc., 68, 122-128 (2013). DOI: https://doi.org/10.1016/j.vibspec.2013.06.003

[10] Z. Abdija, M. Najdoski,V. Koleva, T. Runčevski, R. E. Dinnebier, B. Šoptrajanov, V. Stefov, Preparation, structural, thermogravimetric and spectroscopic study of magnesium potassium arsenate hexahydrate, Z. Anorg. Allg. Chem., 640, 3177-3183 (2014). DOI: https://doi.org/10.1002/zaac.201400265

[11] V. Koleva, V. Stefov, M. Najdoski, A. Cahil, Thermal, spectral and microscopic studies of water-rich hydrate of the type $\mathrm{Mg}_{2} \mathrm{KH}\left(\mathrm{PO}_{4}\right)_{2} \cdot 15 \mathrm{H}_{2} \mathrm{O}$. Thermal transformations, Thermochim. Acta, 619, 20-25 (2015). DOI: https://doi.org/10.1016/j.tca.2015.09.016

[12] V. Koleva, V. Stefov, M. Najdoski, Characterization and thermal decomposition of $\mathrm{Mg}_{2} \mathrm{KH}\left(\mathrm{AsO}_{4}\right)_{2} \cdot 15 \mathrm{H}_{2} \mathrm{O}, J$. Therm. Anal. Calorim., 127, 1911-1919 (2017). DOI: 10.1007/s10973-016-5782-2

[13] V. Stefov, V. Koleva, M. Najdoski, Z. Abdija, A. Cahil, B. Soptrajanov, Vibrational spectra of $\mathrm{Mg}_{2} \mathrm{KH}\left(\mathrm{XO}_{4}\right)_{2} \cdot 15 \mathrm{H}_{2} \mathrm{O}$ $(\mathrm{X}=\mathrm{P}, \mathrm{As})$ containing dimer units $\left[\mathrm{H}\left(\mathrm{XO}_{4}\right)_{2}\right]$, Spectrochim. Acta A, 183, 387-394 (2017). DOI: https://doi.org/10.1016/j.saa.2017.04.031

[14] M. Pecovska-Gjorgjevich, V. Stefov, M. Najdoski, V. Koleva, S. Mentus, G. Petruševski, $\mathrm{Mg}_{2} \mathrm{KH}\left(\mathrm{XO}_{4}\right)_{2} \cdot 15 \mathrm{H}_{2} \mathrm{O}$ 
$(\mathrm{X}=\mathrm{P}$, As $)$ containing acidic dimer units: electrochemical impedance spectroscopy, IR spectroscopy and DSC studies, J. Alloys Compd., 746, 699-709 (2018). DOI: https://doi.org/10.1016/j.jallcom.2018.02.348

[15] W. Massa, O. V. Yakubovich, O. V. Dimitrova, A new cubic form of a caesium hexaaquamagnesium phosphate, Acta Crystallogr., C59, i83 (2003). DOI: https://doi.org/10.1107/S0108270103011417

[16] M. Weil, Redetermination of the hexagonal struvite analogue $\mathrm{Cs}\left[\mathrm{Mg}\left(\mathrm{OH}_{2}\right)_{6}\right]\left(\mathrm{PO}_{4}\right)$, Acta Crystallogr., E64 i50 (2008). DOI: https://doi:10.1107/S1600536808023283

[17] M. Weil, Redetermination of the cubic struvite analogue $\mathrm{Cs}\left[\mathrm{Mg}\left(\mathrm{OH}_{2}\right)_{6}\right]\left(\mathrm{AsO}_{4}\right)$, Acta Crystallogr., E65, i2 (2009). DOI: https://doi.org/10.1107/S1600536808043171

[18] G. Carver, C. Dobe, T. B. Jensen, P. L. W. TregennaPiggott, S. Janssen, E. Bill, G. J. McIntyre, A. L. Barra, Spectroscopic, magnetochemical and crystallographic study of cesium iron phosphate hexahydrate: Characterization of the electronic structure of the iron(II) hexaaqua cation in quasicubic environment, Inorg. Chem., 45, 4695-4705 (2006). DOI: 10.1021/ic0601889

[19] GRAMS ANALYST ${ }^{\mathrm{TM}}$ for PE-2000 FT-IR, Version 3.01B Level II, Galactic Industries, 1994.

[20] GRAMS/32 Spectral Notebase, Version 4.10, Galactic Industries Corporation, 1996.

[21] H. D. Lutz, Bonding and structure of water molecules in solid hydrates. Correlation of spectroscopic and structural data, Struct. Bonding, 69, 97-125 (1988).
[22] M. Falk, O. Knop, in: Water: A Comprehensive Treatise, Vol. 2, F. Frank (Ed.), Plenum Press, New York, 1973.

[23] V. P. Tayal, B. K. Srivastava, D. P. Khandewal, H. D. Bist, Librational modes of crystal water in hydrated solids, Appl. Spectrosc. Rev., 16, 43-134 (1980). DOI: https://doi.org/10.1080/05704928008081709

[24] K. Ichida, Y. Kuroda, D. Nakamura, M. Kubo, Librational spectra of water molecules in some transition metal dichloride dihydrates, Spectrochim. Acta, 28A, 2433 2441 (1972). DOI: https://doi.org/10.1016/0584-8539(72)80222-8

[25] A. Eriksson, J. Lindgren, Model calculations of the vibrations of bonded water molecules, J. Mol. Struct., 48, 417-430 (1978). DOI: https://doi.org/10.1016/0022-2860(78)87252-4

[26] H. D. Lutz, H. J. Kluppel, W. Pobitshka, B. Boosner, Assignment of the rotatory vibrations of water molecules in crystal hydrates, Z. Naturforch, 29B, 723-726 (1974). DOI: https://doi.org/10.1515/znb-1974-11-1206

[27] T. Miyzawa, Infrared studies of the librations of water molecules in the solid matrices at $20 \mathrm{~K}$, Bull. Chem. Soc. Jpn., 34, 202-205 (1961).

DOI: https://doi.org/10.1246/bcsj.34.202

[28] H. D. Lutz, H. Christian, Librational modes of the water molecules in barium and strontium halide monohydrates, $\mathrm{MX}_{2} \cdot \mathrm{lH}_{2} \mathrm{O}(\mathrm{M}=\mathrm{Ba}, \mathrm{Sr} ; \mathrm{X}=\mathrm{Cl}, \mathrm{Br}, \mathrm{I})$, J. Mol. Struct., 101, 199-212 (1983).

DOI: https://doi.org/10.1016/0022-2860(83)85013-3 
